ОСОБЛИВОСТІ ҐЕНДЕРНИХ СТЕРЕОТИПІВ СЕРЕД ЧОЛОВІКІВ І ЖІНОК СЕРЕДНЬОГО ВІКУ

\title{
FEATURES OF GENDER STEREOTYPES AMONG MIDDLE-AGE MEN AND WOMEN
}

УДК 159.923.2

DOI https://doi.org/10.32843/2663-

5208.2021.31.37

\section{Полшкова С.Г.}

д.мед.н.,

просресор касредри клінічної психології ТОВ «Київський інститут сучасної

психології та психотерапії»

\section{Трофрімова д.о.}

к.психол.н.

доцент кафедри соціальної психології ТОВ «Київський інститут сучасної психології та психотерапії»

\section{Крайлюк A.I.}

к.психол.н.,

доцент кафедри соціальної психології ТОВ «Київський інститут сучасної

психології та психотерапії»

\begin{abstract}
у статті розглянуто поняття ґендеру як цілісної психічної репрезентації статі, що відповідає поняттям «жіноче» $i$ «чоловіче» та здобута індивідом у результаті індивідуального досвіду. Визначено, що ґендер відображає «соціальну» стать, на відміну від біологічної, і може мати постійний чи змінний характер. Для проведення дослідження ґендерних стереотипів обрано метод «Особистісний семантичний дифреренціал» О.Л. Кустової, що розкриває ґендерний аспект власного «Я» досліджуваних і дає змогу визначити поведінкові моделі респондента та його уявлення про ідеальний образ і призначення відповідно до його статі. у дослідженні взяли участь 83 особи віком від 25 до 45 років обох статей. Для дослідження ссрормовано дві групи: чоловіча (40 осіб) і жіноча (43 особи).

Підтверджено, що гіпергендерність як ознака «типової» чоловічої або жіночої поведінки є завадою для особистісного розвитку, унаслідок надмірної поляризації обов'язків i фрункцій за ознакою статі. З'ясовано, що присутність ґендерно-рольових стереотипів сповільнює процес саморозвитку та самовираження особистості. Також представниці жіночої групи проявляють і за окремими фракторами й перевищують якості нарівні з чоловіками, що направлені на досягнення успіху у власній реалізації та зміцнення соціальних позицій. При такій тенденції водночас спостерігається прагнення жінок до зменшення емпатійності й емоційності як традиційно жіночих якостей задля досягнення успіху в різних ссрерах суспільного життя. Отримані результати засвідчують про зміну уявлень у поглядах сучасності відносно чоловічого й жіночого образу, які відходять від традиційних ролей і стереотипів. Ключові слова: ґендер, стереотипи, образ «Я», фремінність, маскулінність, андрогінHicmb.
\end{abstract}

The article considers the concept of gender as a holistic mental representation of sex, which corresponds to the concepts of "female" and "male" and acquired by the individual as a result of individual experience. It is determined that gender reflects the "social" sex as opposed to the biological one, and can be permanent or variable. The method of "Personal Semantic Differential" by O. Kustova was chosen to conduct a study of gender stereotypes, which reveals the gender aspect of the respondents own "self" and allows to determine oneself's behavioral models and their idea of the ideal image and purpose in accordance with their gender. The study involved 83 people aged 25 to 45 years, which included representatives of both sexes. Two groups were formed for the study, that are male (40 people) and female (43 people).

It has been confirmed that hypergender, as a sign of "typical" male or female behavior, is an obstacle to personal development, due to excessive polarization of responsibilities and functions on the sex basis. It has been found that the presence of gender role stereotypes slows down the process of self-development and self-expression. Also, the representatives of the women's group show and on some factors exceed the qualities on a par with men, which are aimed at achieving success in their own implementation and strengthening social positions. At the same time, this tendency shows the desire of women to reduce empathy and emotionality as traditionally female qualities in order to achieve success in various spheres of public life. The obtained results testify to the change of ideas in the views of modernity regarding the male and female image, which deviate from traditional roles and stereotypes.

Key words: gender, stereotypes, self-image, femininity, masculinity, androgyny.
Стереотипи досі відіграють значущу роль у формуванні та становленні свідомості сучасної людини. Незважаючи на демократичність українського суспільства й забезпечення для обох статей рівних можливостей у доступі до освіти й охорони здоров'я, простежуються деякі тенденції нерівноправності жінок у можливості при виборі майбутньої професії, прийнятті на роботу, винагороді за працю, існуе дисбаланс у співвідношенні жінок і чоловіків на керівних та управлінських посадах, менеджменту й у сфері політики. Тож цілком актуальним постає питання, чи дійсно у XXI столітті ґендерні стереотипи є причиною цієї диспропорції, наскільки сильно самі жінки схильні до стереотипного бачення себе і світу.

Метою статті є дослідити психологічні особливості ґендерних стереотипів серед чоловіків і жінок середнього віку.
Вивченню ґендеру присвятили роботи $€$ Є.П. Ільїн (соціальна природа ґендеру) [1], Ш. Берн (підпорядкування ґендерним нормам) [6], Є. Ніколаєва (психофізіологічна детермінація ґендерних відмінностей) [4], С. Бем (теорія ґендерних схем), Д. Батлер.

Дослідження ґендерних ролей і стереотипів переважно базуються на ідеях соціальноконструктивістської парадигми, у контексті якої ґендер розуміється як соціально сконструйовані відносини за ознакою статі. Соціально-конструктивістський підхід до аналізу ґендерно-рольових стереотипів базується на твердженні, що в соціальному розумінні жінки та чоловіки утворюються самим суспільством, а не народжуються. Робиться акцент на те, що не існує «жіночого» та «чоловічого» як природного й незмінного факту, а ґендерні ролі формуються як наслідок тривалої, постійно 
відтворюваної взаємодії між людьми. Дослідники цього підходу стверджують, що відмінності, які в суспільстві, визначаються як маскулінні та фемінні, наявні статусно-рольові характеристики чоловіка і жінки не мають біологічного підґрунтя. Це лише засіб інтерпретації біологічного, а анатомічні відмінності не повинні бути визначальними в соціальній долі ні для жінок, ні для чоловіків [5]. Структура дослідження побудована відповідно до соціально-конструктивістської парадигми, ураховуючи статево-рольові відмінності при вивченні впливу ґендерних стереотипів серед чоловіків і жінок.

Дослідження впливу ґендерних стереотипів серед чоловіків і жінок проведено в березні 2021 року в місті Києві. Вибірка становила 83 особи віком від 25 до 45 років, до якої ввійшли представники обох статей. Для дослідження сформовано дві групи: чоловіча (40 осіб) і жіноча (43 особи).

Для дослідження був обраний вік від 25 до 45 років, проте більша частина респондентів належить до вікової категорії від 36 до 45 років. Саме для цього вікового періоду характерні найвищі показники інтелектуального, психологічного та соціального розвитку особистості. Тому очікуваним є те, що саме в цей період найактивніше відбувається процес самоактуалізації як у чоловіків, так і в жінок.

Практична частина емпіричного дослідження проводилася в три етапи. На першому етапі проведено процедури діагностики, застосовуючи метод «Особистісний семантичний диференціал» (О.Л. Кустова). На другому етапі проведено узагальнення всіх даних і формування двох груп: чоловічої та жіночої. На третьому етапі здійснювався статистичний аналіз за допомогою програми статистичної обробки Jamovi й інтерпретація отриманих даних.

Аналіз та інтерпретація одержаних у ході емпіричного дослідження результатів включали декілька етапів. На першому етапі проведений аналіз внутрішньої надійності

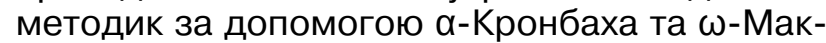
дональдса. Для методу «Особистісний семантичний диференціал» (О.Л. Кустова) отримано такі показники: $\alpha$-Кронбаха $=0,980$, $\omega$-Макдональдса = 0,980. Отримані результати свідчать про надійність та узгодженість питань в обраних методиках.

Наступний крок аналізу полягав у вивченні описових статистик і проведенні порівняльного аналізу за методикою «Особистісний семантичний диференціал» (О.Л. Кустова) з метою виявлення стереотипності поглядів щодо жіночого і чоловічого образу для респондентів жіночої та чоловічої групи відповідно.

Досліджуваним пропонувалося дати характеристику так: «Жінка на відміну від чоловіка»
(«Чоловік на відміну від жінки»), образу «Я», «деальна жінка» («деальний чоловік»), «Призначення жінки» («Призначення чоловіка»). Образ «Жінка на відміну від чоловіка» («Чоловік на відміну від жінки») досліджувався згідно з методикою в такому варіанті: необхідно було позначити ступінь відмінності між жінкою та чоловіком і навпаки, на думку респондентів.

Усі шкали згруповано для факторного аналізу, результати підсумовано, обчислено середні показники для кожного фактора. Для аналізу виділено низку факторів:

- оцінки загальної привабливості;

- сили особистості;

- емоційності;

- соціального статусу;

- залежності;

- емпатійності;

- сучасності;

- Фемінності (традиційно «жіночих» якостей);

- маскулінності (традиційно «чоловічих» якостей);

- андрогінності (ґендерно нейтральних якостей).

Шкали, з яких згруповано фактори, оцінювалися у відсотках $(10,20,30 \ldots 100 \%)$, для подальшої статистичної обробки переводилися в бали від 0 до 10 (відповідно 1 бал - це 10\%, 2 бали - це 20\% тощо).

Необхідно зауважити, що до факторів емоційності, залежності, соціального статусу входить п'ять шкал, тому максимально можливий результат становить 50. Для фактору сила особистості максимальне значення - 70, оскільки містить у собі сім шкал. До факторів оцінки загальної привабливості, емпатійності, фемінності, андрогінності входить по вісім шкал, а отже, максимальний показник - 80. До факторів сучасності й маскулінності входить по дев'ять шкал, тому максимальне значення можна отримати 90.

Обчислені середні показники по кожному фактору для образів «Ідеальна жінка» («Ідеальний чоловік»), «Призначення жінки» («Призначення чоловіка») й образу «Я» відображають ступінь виразності традиційного, стереотипного погляду на жінку або чоловіка, а також стереотипність поведінкової моделі респондентів.

Обчислений середній показник по кожному фактору для образу «Жінка на відміну від чоловіка» («Чоловік на відміну від жінки») відображає різницю між чоловіком і жінкою з точки зору досліджуваних (табл.1).

Для фактора оцінки загальної привабливості для образу «Жінка на відміну від чоловіка» («Чоловік на відміну від жінки») отримано такі показники: середнє арифметичне для жінок 40,1 при стандартному відхиленні 20,5 і максимальному 65; для чоловіків середнє 
Показники по факторах по жіночій і чоловічій групах

Таблиця 1

\begin{tabular}{|l|c|c|c|c|}
\hline & Група & $\begin{array}{c}\text { Фактор оцінки } \\
\text { загальної } \\
\text { приваливості } \\
\text { /відмінність }\end{array}$ & $\begin{array}{c}\text { Фактор сили } \\
\text { особистості } \\
\text { /відмінність }\end{array}$ & $\begin{array}{c}\text { Фактор } \\
\text { емоційності } \\
\text { /відмінність }\end{array}$ \\
\hline \multirow{2}{*}{ Кількість } & жінка & 43 & 43 & 43 \\
\cline { 2 - 5 } & чоловік & 40 & 40 & 40 \\
\hline \multirow{2}{*}{ Мереднє арифметичне } & жінка & 40,1 & 26,3 & 26,2 \\
\cline { 2 - 5 } & чоловік & 32,2 & 35,4 & 22,0 \\
\hline \multirow{2}{*}{$\begin{array}{l}\text { Стандартне } \\
\text { відхлення }\end{array}$} & жінка & 46 & 30 & 26 \\
\hline Мінімальне & жінка & 35,0 & 21,4 & 11,3 \\
\cline { 2 - 5 } & чоловік & 20,5 & 17,7 & 13,3 \\
\cline { 2 - 5 } & жінка & 19,7 & 0 & 0 \\
\hline \multirow{2}{*}{ Максимальне } & жінка & 0 & 0 & 0 \\
\cline { 2 - 5 } & чоловік & 65 & 64 & 44 \\
\hline
\end{tabular}

арифметичне становить 32,2 при стандартному відхиленні 19,7 та максимальному 73. Обчислений середній показник по кожному фактору для образу «Жінка на відміну від чоловіка» («Чоловік на відміну від жінки») відображає різницю в процентному співвідношенні між чоловіком і жінкою та навпаки.

Таким чином, на думку представниць жіночої групи, жінки, на відміну від чоловіків, більш привабливі на 40,1\%. Чоловіки вважають себе привабливішими на $32,2 \%$.

За фактором сили особистості отримано середні значення для жінок 26,3 при стандартному відхиленні 21,4 та максимальному 64, а для чоловіків середне становить 35,4 при стандартному відхиленні 17,7 та максимальному 61. Отже, жінки вважають себе сильнішими на 26,3\%, ніж чоловіки, а чоловіки приписують силу власній особистості на $35,4 \%$ більшу, ніж у представниць жіночої статі.

За фактором емоційності отримано середне значення для жінок 26,2 при стандартному відхиленні 11,3 і максимальному 44, а для чоловіків середнє 22,0 при стандартному відхиленні 13,3 та максимальному 40. Отже, такі дані говорять, що жінки вважають себе більш емоційними на $26,2 \%$, ніж чоловіки, а чоловіки вважають, що вони емоційніші за жінок на 22\%.

Далі проведений порівняльний аналіз за такими факторами: фактор соціального статусу, фактор залежності, фактор емпатійності, фактор сучасності.

Жінки вважають себе на 20,3\% впевненіші щодо соціального становища, яке вони займають у суспільстві, ніж чоловіки. Для чоловіків характерне переконання, що вони мають на 24,2\% впевненіші позиції, ніж жінки, у реалізації власних позицій у соціумі.

Для фактору залежності, що відображає ступінь залежності від певних людей та обста- вин, можна сказати, що жінки вважають себе на 26,5\% більше, ніж чоловіки, залежними від певних аспектів буття. Чоловіки вважають себе більш залежними, на відміну від жінок, що становить $19,7 \%$.

За наступним фактором жінки вважають себе емпатійнішими на 41,55\%, ніж чоловіки. Чоловіки встановили ступінь різниці в 29,3\% власної емпатійності порівняно із жінками (табл. 2).

За фактором сучасності, що відображає здатність відчувати тенденції змін у навколишньому світі, у суспільстві та здатність адаптуватися до цих змін, отримано такі висновки. Жінки вважають себе на 34,5\% здатними слідувати відповідно до змін сучасності, на відміну від чоловіків. Для чоловіків отримано показник у 46,4\%, що говорить про те, що чоловіки вважають для себе більш характерними вищезазначені характеристики.

Наступні три фактори розглянуто окремо, 3 огляду на те що, згідно з методикою, фактор фемінності визначається лише для жінок, а фактор маскулінності - лише для групи чоловіків. Фактор андрогінності, що свідчить про ґендерно нейтральні якості, визначався й для чоловічої, і для жіночої групи (табл. 3).

Виявилося, що жінки при оцінці образу «Жінка на відміну від чоловіка» приписують жіночі якості на 48,8\%, а чоловіки вважають себе більш мужніми на 56\%, на відміну від представниць протилежної статі. За фактором андрогінності респонденти показали близькі значення: жінки - 37,9\%, чоловіки - 36\%.

Проаналізувавши отримані дані за образом «Жінка на відміну від чоловіка», можна стверджувати, що респондентам жіночої групи властиві переконання, що жінка більш емоційна й емпатична, має привабливішу зовнішність, проте на кілька сходинок нижче стоїть за 
Показники по Факторах по жіночій і чоловічій групах

\begin{tabular}{|c|c|c|c|c|c|}
\hline & Група & $\begin{array}{c}\text { Фактор } \\
\text { соціального } \\
\text { статусу } \\
\text { /відмінності }\end{array}$ & $\begin{array}{c}\text { Фактор } \\
\text { залежності } \\
\text { /відмінності }\end{array}$ & $\begin{array}{c}\text { Фактор } \\
\text { емпатійності } \\
\text { /відмінності }\end{array}$ & $\begin{array}{c}\text { Фактор } \\
\text { сучасності } \\
\text { /відмінності }\end{array}$ \\
\hline \multirow[t]{2}{*}{ Кількість } & жінка & 43 & 43 & 43 & 43 \\
\hline & чоловік & 40 & 40 & 40 & 40 \\
\hline \multirow[t]{2}{*}{ Середнє } & жінка & 20,3 & 26,5 & 41,5 & 34,5 \\
\hline & чоловік & 24,2 & 19,7 & 29,3 & 46,4 \\
\hline \multirow[t]{2}{*}{ Медіана } & жінка & 19 & 31 & 50 & 31 \\
\hline & чоловік & 26,0 & 19,0 & 33,0 & 52,0 \\
\hline \multirow{2}{*}{$\begin{array}{l}\text { Стандартне } \\
\text { відхилення }\end{array}$} & жінка & 14,4 & 11,4 & 19,9 & 25,9 \\
\hline & чоловік & 13,7 & 13,1 & 20,2 & 24,2 \\
\hline \multirow[t]{2}{*}{ Мінімальне } & жінка & 0 & 0 & 0 & 0 \\
\hline & чоловік & 0 & 0 & 0 & 0 \\
\hline \multirow[t]{2}{*}{ Максимальне } & жінка & 42 & 42 & 69 & 71 \\
\hline & чоловік & 46 & 41 & 66 & 78 \\
\hline
\end{tabular}

Показники по факторах по жіночій і чоловічій групах

\begin{tabular}{|l|c|c|c|c|}
\hline & Група & $\begin{array}{c}\text { Фактор фемінності / } \\
\text { відмінності }\end{array}$ & $\begin{array}{c}\text { Фактор } \\
\text { маскулінності } \\
\text { /відмінності }\end{array}$ & $\begin{array}{c}\text { Фактор } \\
\text { андрогінності } \\
\text { /відмінності }\end{array}$ \\
\hline \multirow{2}{*}{ Кількість } & жінка & 43 & - & 43 \\
\cline { 2 - 5 } $\begin{array}{l}\text { Середне } \\
\text { арифметичне }\end{array}$ & жінка & - & 40 & 40 \\
\cline { 2 - 5 } & чоловік & 48,8 & - & 37,9 \\
\hline \multirow{2}{*}{ Медіана } & жінка & - & 46,0 & 36,0 \\
\cline { 2 - 5 } & чоловік & 59 & - & 41 \\
\hline \multirow{2}{*}{$\begin{array}{l}\text { Стандартне } \\
\text { віхилення }\end{array}$} & жінка & - & 49,0 & 37,5 \\
\hline \multirow{2}{*}{ Мінімальне } & чоловік & - & - & 20,7 \\
\hline \multirow{2}{*}{ Максимальне } & жінка & 24,9 & 0 \\
\cline { 2 - 5 } & чоловік & - & - & 0 \\
\cline { 2 - 5 } & жінка & 68 & - & 64 \\
\hline
\end{tabular}

соціальним статусом у суспільстві, ніж чоловіки, і займає більш залежну позицію в повсякденному житті. Цікавим виявився той факт, що традиційно жіночі якості займають середні позиції прояву цього образу, зіставляючи які з проявом нейтральних ґендерних ознак, можна висунути припущення, що в сучасних поглядах відбуваються зміни щодо традиційності уявлень жіночого образу.

Відповідно до результатів для чоловічої групи щодо образу «Чоловік на відміну від жінки» отримано такі характеристики: чоловіки впевненіші щодо власної соціальної позиції, менш залежні від різноманітних факторів, більше відповідають наявним сучасним тенденціям у суспільстві. Респонденти чоловічої групи вважають чоловіків досить привабливими, емоційними, емпатійними, проте порівняно із жіночою групою ці показники значно нижчі. За проявом традиційно чоловічих якостей для цього образу характерні середні показники, які в поєднанні 3 показниками андрогінності можуть указувати на те, що відбувається трансформація чоловічого образу сучасності.

Далі, згідно з методикою, проводився порівняльний аналіз образу «Я» 3 «деальним образом» та образом «Призначення» як у жіночій, так і в чоловічій групі за всіма зазначеними факторами.

При порівнянні по обом групам образу «Я», «Ідеального образу» та «Призначення» за фактором оцінки привабливості необхідно відмітити, що жінки вбачають в ідеальному образі жінки більшу привабливість, ніж притаманна їм у власному образі «я». Для власного образу «я» 62,4\% - середня оцінка себе респондентом (при стандартному відхиленні 9,87, 
максимальному 75 та мінімальному 36). Для ідеального образу показник збільшується до 65,7\%, але в образі «Призначення жінки» відмічається заниження цього показника до 61\%. Таке зниження можна пояснити можливим впливом наявних поглядів щодо образу реалізованої жінки в частини досліджуваних жінок. Проте треба зазначити, що максимально можливий показник за фактором становить 80. Отримані дані для образу «Призначення» - 61,0, ураховуючи стандартне відхилення 19,8 при максимальному 80 та мінімальному 36, свідчать про традиційність поглядів на оцінку досліджуваного образу в індивідуальному сприйнятті окремих представниць жіночої групи.

За фактором привабливості чоловіки вбачають «деальний образ» $(61,1 \%)$, що значно більше, ніж для власного образу «я» (53,6\%). Проте, необхідно зазначити, що різниця між показниками образами «я» та образом «Призначеннячоловіка» незначна. Це може свідчити про те, що респонденти не мають завищених вимог і стандартів щодо власної зовнішності задля реалізації свого призначення.

За фактором сили особистості жінки прагнуть стати набагато сильнішими й до особистісного зростання. Про це свідчить зростання до 60,2\% з 54\% показника «деальний образ жінки», а також наближення показника ідеального образу 60,2 до максимально можливого. Незначний відрив між показником образу «я» та «Призначення жінки» $(56,4 \%)$ за фактором сили особистості може свідчити про все ще вплив стереотипного уявлення про жінку як про «слабку особистість».

Для чоловіків дещо більша різниця між показниками образу «я» $(50,9 \%)$ та ідеальним образом чоловіка (57\%), образом «Призначення чоловіка» $(55,2 \%)$ за фактором «Сили особистості». Проте необхідно зазначити, що для респондентів чоловічої групи показники ідеалу не відповідають занадто високим, якщо враховувати, що максимально можливе значення за цим фактором 70. Можна припустити, що сучасність не вимагає вияву від чоловіків «міцності духу», а отже, це відображається й на уявленні про ідеали.

Далі вивчався фактор емоційності по обох групах.

За фактором емоційності максимально можливий результат становить 50. Відмічається вище середнього прояв за цією ознакою в чоловіків (середнє арифметичне 29,5 при стандартному відхиленні 7,40 та максимальному 44), середній у жінок (середнє арифметичне 27,2 при стандартному відхиленні 8,02 та максимальному 39). За цим фактором простежується намагання жінок проявляти меншу емоційність в ідеальному образі жінки $(22,7 \%)$ порівняно з власним образом «я»
(27,2\%), така ж тенденція й щодо образу «Призначення жінки» (24\%). Для чоловіків ідеальний образ та образ «Призначення чоловіка» майже рівні за значенням - 28,5\% та 28,4\% відповідно. Для реального образу «Я» це значення становить $29,5 \%$.

Отже, і для чоловіків, і для жінок простежується прагнення емоційної стійкості, яка $€$ необхідною для самореалізації, неодмінним складником самоактуалізованої особистості. Для жінок простежується стійка тенденція прагнення долати зайву емоційність. На нашу думку, це може бути зумовлено стереотипними уявленнями, наявними в суспільстві, щодо несумісності емоційності 3 діловими якостями й управлінською діяльністю.

Якщо розглядати емпатійність за всіма образами, то спостерігається той факт, що для жінок характерний прояв на одному рівні: для образу «я» - 52,6\%, «Ідеальний образ жінки» $52,0 \%$, «Призначення жінки» - 51\%.

Для чоловіків емпатійність для образу «я» становить $47,6 \%$, а для ідеального образу чоловіка - 51,6\%, для образу «Призначення чоловіка» - 51\%. Це може свідчити про прагнення чоловіків розуміти інших, застосовуючи механізми емпатії. Для жінок же характерне прийняття своїх емпатійних здібностей як традиційно жіночих, проте можливе прагнення дещо нижче проявляти емпатійність у процесі реалізації призначення. Необхідно відмітити, що максимально можливе значення за цим фактором становить 80. Таким чином, як для жінок , так і для чоловіків характерний вище середнього прояв за цією ознакою.

Далі вивчалися результати за фактором соціального статусу.

Порівнюючи показники за фактором соціального статусу, за яким максимально можливий показник становить 50, необхідно відмітити, що як для досліджуваних жінок, так і для чоловіків простежується намагання зміцнити власні соціальні позиції. Це підтверджено значною різницею між реальним «Я» (для жінок - 34\%, для чоловіків - 32,9\%) та ідеальним образом (для жінок - 40,6\%, для чоловіків - 39,7\%), образом призначення (для жінок - 37,9\%, для чоловіків - 39,5\%). Це пояснюється наявними в суспільстві стандартами успішності. Набутий соціальний статус - статус, якого людина досягає завдяки своїм розумовим і фізичним зусиллям (робота, зв'язки, посада, пост). І простежується стійка тенденція серед жінок на рівні з чоловіками проявляти прагнення досягати стійких позицій у соціумі, реалізувати власні можливості через власну діяльність. Цей висновок підтверджується й висновками щодо фактору залежності.

За фактором залежності в жінок простежується намагання відходити від позицій залежності. Якщо для образу «Я» показник 
становить 28\%, то для образу «деальна жінка» цей показник - 24,2\%, а для образу «Призначення жінки» - 25,1\%. Для чоловіків всі три образи знаходяться в показниках на одному рівні: образ «я» - 26,5\%, «ддеальний чоловік» - 26,6\%, «Призначення чоловіка» 25,9\%. Ураховуючи, що максимально можливий результат за цим фактором - 50, необхідно відзначити, що загалом і для жінок, і для чоловіків характерний прояв за цією ознакою в межах середніх значень. Необхідно звернути увагу на те, що для чоловіків питання залежності не $є$ актуальним, зважаючи на досить рівні значення за показниками трьох образів, на відміну від жінок. Тобто, беручи до уваги результати за фактором соціального статусу та розглянутим фактором залежності, необхідно звернути увагу на прагнення жінок сучасного суспільства досягати успіху, але це супроводжується подоланням більш залежних позицій, ніж у чоловіків. Можна припустити, що це зумовлено ще наявними стереотипами в соціумі.

Для представниць жіночої статі досліджуваної вибірки спостерігається прагнення слідувати відповідно до нових обставин сучасності, знаходитися в потоці соціального життя й відчувати тенденції змін у соціумі. Це виявляється в показниках для образу «деальна жінка» $(75,4 \%)$ та «Призначення жінки» $(68,7 \%)$ порівняно за образом «я» $(65,4 \%)$. Для представників чоловічої групи відзначаються так ж тенденція щодо прояву цього фактору: образ «я» - 63,4\%, «деальний образ» - 72,2\%, «Призначення чоловіка» 70,9\%. Максимально можливий результат за цим фактором становить 90, тому й для чоловічої, і для жіночої групи прояв за цією ознакою вище середнього.

У ході аналізу жіночого образу сучасності наступним кроком було порівняння фактору фемінності за образом «я», «деальний образ жінки», «Призначення жінки».

Середнє арифметичне для власного образу «Я» становить 58,3\%, для ідеального образу - 53,7\% та для образу «Призначення жінки» - 52,6\%. Отже, можна зробити висновок, що жінки вважають себе надто жіночими. І для ідеального жіночого образу, і для успішно реалізованої жінки за власним призначенням респодентки вбачають необхідність меншого прояву традиційних жіночих якостей. Однак якщо враховувати, що можливий максимальний результат за цим фактором становить 80, то прояв фемінних якостей у досліджуваних жінок незначно перевищує середні позиції (середнє арифметичне 58,3 при стандартному відхиленні 8,77, максимальному 71 та мінімальному 39).
Ураховуючи, що максимально можливий результат за фактором маскулінності за образом «Я», «деальний образ чоловіка», «Призначення чоловіка» становить 90, то відзначається вище середнього прояв маскулінних якостей (середнє 64,7 при стандартному відхиленні 10,0, максимальному 73 та мінімальному значенні 36). Отже, навіть максимально отриманий результат з вибірки не відповідає високим значенням. Власному образу «Я» чоловіки відвели 64,7\% прояву традиційно чоловічих якостей, а от для ідеального образу чоловіка респонденти вбачають прояв маскулінності на $73,1 \%$, а для образу «Призначення чоловіка» на $72,7 \%$. Отже, чоловікам, на відміну від жінок, навпаки, притаманне бажання слідувати більш традиційним поглядам на образ чоловіка відповідно до «чоловічих стандартів», проте ці стандарти не відповідають жорстким межам традиційних стереотипів. Так, різниця в поглядах на відповідний ідеальний образ у чоловічій і жіночій групі пояснюється наявними критеріями успішності в суспільстві й вимогами щодо особистості, що реалізується в площині власної діяльності. Ці вимоги передбачають передусім прояв певних маскулінних якостей, тому бажання жінок зменшити прояв своїх фемінних якостей задля досягнення успіху є передбачуваним.

Висновки з проведеного дослідження. За методикою «Особистісний семантичний диференціал» О.Л. Кустової фактори «емоційності», «залежності», «емпатійності», «фемінінності» відображають досить традиційні погляди на образ жінки, тому високі показники по цій групі вказують на традиційну оцінку досліджуваних образів. У поглядах сучасних жінок відбуваються зміни щодо уявлень жіночого образу, які відходять від традиційних стереотипів. Підтвердження цього факту ми знаходимо в більш високих показниках серед жіночої групи, ніж чоловічої, за фактором «сили особистості», фактором «соціального статусу» й фактором «сучасності".

За методикою високі значення за факторами «сили особистості», «соціального статусу», «сучасності», «маскулінності» говорять про досить традиційні погляди на досліджувані образи в чоловіків. При дослідженні чоловічої групи отримано вище середнього показники за фактором «соціального статусу» і за фактором «сучасності», середні показники за фактором «сили особистості» й «маскулінністю». Ураховуючи, що результати за «емоційним» та «емпатійним» фактором вище середнього, можна зробити висновок, що відбувається трансформація чоловічого образу порівняно з традиційними поглядами. 


\section{ЛІТЕРАТУРА:}

1. Щотка О.П. Гендерна психологія : навчальний посібник. Ніжин : Видавець ПП Лисенко М.М., 2019. $359 \mathrm{c}$.

2. Де Бовуар С. Второй пол. Москва : Прогресс ; Санкт-Петербург : Алетейя, 1997. 832 с.

3. Unger R. Toward a Redefinition of sex and Gender. American Psychologist. 1979. № 3. P. 43-57.
4. Зравомыслова Е.А., Темкина А.А. Социальное конструирование гендера. Москва, 2002. $176 \mathrm{c}$.

5. Основи теорії гендеру : навчальний посібник. Київ : К.І.С., 2004. 536 с.

6. Берн Ш. Гендерная психология. Санкт-Петербург : прайм-ЕВРОЗНАК, 2004. 320 с. 